\title{
Voorwoord
}

Op 31 Mei 2015 het die oud-dosent, veelsydige literator, digter, prosaïs en dramaturg T.T. Cloete 91 jaar oud geword.

Sedert hy in Desember 2009 'n vorige keer deur vakkollegas en oud-studente in Tydskrif vir Geesteswetenskappe gehuldig is vir sy bydraes op so 'n verskeidenheid terreine van die Afrikaanse letterkunde, het nog vier publikasies uit sy pen die lig gesien: 'n versversamelbundel opgedra aan sy oorlede vrou, Anna, getiteld Uit die wit lig van my land gesny (2010); 'n poësiebeskoulike prosawerk, Die ander een is ek (2013); en die digbundels Onversadig (2011) en Karnaval en Lent is een gedig (2014). Die vier artikels en nege gedigte in hierdie tydskrifnommer is eweneens die werk van literêre en digterkollegas en/of oud-studente van Cloete, spesifiek geskryf ter viering van sy merkwaardige voortgesette produktiwiteit en kreatiwiteit as denker en digter.

Die huldigingsgedigte (wat ' $n$ bydrae uit Nederland insluit) boei onder meer vanweë die wyse waarop nie net lewens- en wêreldbeskoulike aspekte van Cloete se digterskap aangeroer word nie, maar daar ook poësiebeskoulik, stilisties én verstegnies in gesprek met sy digwerk getree word.

Die vier navorsingsartikels dek uiteenlopende aspekte van Cloete se poësie-oeuvre. Marius Crous toon aan dat Cloete sedert sy debuutbundel in 1980 dikwels in sy gedigte 'n sosiaal-kritiese blik op die Suid-Afrikaanse samelewing in die breë werp. Steunend op beskouings en konsepte van Franse denkers soos Rancière, Spivak en Derrida poog Crous om antwoorde te verskaf op vrae oor die mate waarin, én hoedanig, die werklike lot van armes (die subalterne) uitgebeeld word in Cloete se oeuvre. Daar word aangetoon dat Cloete algaande opvallender streef om sy posisie as bevoorregte af te leer en tot selftransenderende empatie met die subalterne te geraak.

Adéle Nel laat val die kollig op die (ernstige!) spel-element as onderdeel van Cloete se poësiebeskouing. Die poësie- en taalspel mond by Cloete onder meer uit in 'n ryke, lewendige intertekstualiteit. Veral die aanknoping wat Cloete se digterlike werkswyse vind by beskouings van die Nederlandse kultuurhistorikus Johan Huizinga kry aandag. 'n Speelse element in Cloete se lewenshouding word uitgelig, asook hoe dit in sy poësieoeuvre en in die poësiebeskoulike Die ander een is ek aansluiting vind by die erotiek en die beswering van eksistensiële lewens- en doodsangs as motiewe. Die verwysingsaspek van Cloete se digterlike werkswyse word ook deur Marlies Taljard onder die loep geneem. Sy doen 'n vergelykende analise van spesifiek sy jongste bundel, Karnaval en Lent is een gedig, en van die skildery deur Pieter Brueghel die Ouere waarop die bundeltitel toespeel, naamlik Die geveg tussen Karnaval en Lent. Motiewe wat aandag kry, sluit die uitbeelding van die tydgenootlike mens in sy toestand van swakheid en verval in, asook die ooreenkomste en verskille tussen die gebruik van simboliek en die uitbeelding van vraatsug as simptoom van 'n ongebalanseerde, skeefgetrekte samelewing in die twee kunswerke. Kennelik word ambivalensie, soos reeds deur die titelelemente "Karnaval" en "Lent" gesinjaleer, as kenmerkend van die menslike kondisie gesien deur beide kunstenaars.

In háár huldiging van Cloete, spesifiek in sy hoedanigheid as literêre teoretikus en oud-dosent, verken Ina Wolfaardt-Gräbe iets van die algemene aard van poësie soos dit geskryf én gelees word, naamlik aan die hand van enkele gedigte uit die Cloete-oeuvre. Die toespitsing is op die klank as toegangspoort tot enkele temas en/of grondliggende vraagstukke wat deurgaans in sy oeuvre ontgin word. Daar word veral gesteun op uitsprake wat Cloete self oor die/sy poësie gemaak het, aangevul met eie navorsing deur Wolfaardt-Gräbe aangaande die aard van poëtiese taalgebruik. Die gedig "stilhuil" (die weergawe gepubliseer in Die ander een is ek) word eerstens gelees deur te fokus op metaforisering, sintaksis, klank en ritme, waarna die kontinuering van die klankmatig vooropgestelde sinsnede "die huid huil luid in stilhuil" in enkele verdere gedigte bekyk word. 
Met dié net minder as 'n hand vol artikels, asook net minder as twee hande vol gedigte, huldig die bydraers tot hierdie Tydskrif vir Geesteswetenskappe-afdeling 'n omvang- en invloedryke, én gelukkig nog onafgehandelde skrywersoeuvre.

\section{Bernard Odendaal}

\section{Gasredakteur}

ATKV-Skryfskool van die Noordwes-Universiteit (Potchefstroomkampus)

Mei 2015 